\title{
PEMBINGKAIAN BERITA KONFLIK BERSENJATA NDUGA DI TABLOIDJUBI.COM
}

\author{
Gita Sere Hutahaen ${ }^{1}$, Formas Juitan Lase ${ }^{2}$ \\ gita.huta@gmail.com \\ Program Studi Ilmu Komunikasi, Universitas Kristen Indonesia
}

\section{Article Info}

Keyword:

Conflict, Framing, Peace Journalism, Papua, Lokal Media

\begin{abstract}
The media has an important role as a mediator in conflict events. That role can be realized through the practice of peace journalism. Peace journalism is the ability of the media to bring conflict events toward peace. The conflict that occurred in Nduga, Papua is one of the important events mediated by the media. There are so many people who are disadvantaged if the media such as Tabloidjubi.com does not report the conflict with a peace journalism approach. This article analyzed the reporting of Tabloidjubi.com using the concept of peace journalism and the method of framing analysis on 15 news in the December 2018 edition. This study tried to see whether Tabloidjubi.com uses the perspective of peace journalism in its reporting. The results showed that Tabloidjubi.com had not applied peace journalism adequately. The news still dominates one side as a cause of conflict, namely the warring elites compared to the creation of peace initiatives. So that the role as a mediator in creating resolution, reconstruction and reconciliation has not yet been realized.
\end{abstract}

Copyright (C) 2021 Interaksi: Jurnal Ilmu Komunikasi.

\section{PENDAHULUAN}

Pada awal Desember 2018, warga sipil yang bekerja di proyek pembangunan jembatan Trans Papua menjadi korban penembakan. Peristiwa tersebut diberitakan oleh banyak media. Kompas.com memberitakan bahwa penembakan dilakukan secara sadis oleh Kelompok Kriminal Bersenjata (KKB) kepada 31 pekerja pembangunan jalan Trans Papua tersebut (Kompas.com, 3 Desember 2012). Masih dari berita yang sama disebutkan bahwa para pekerja yang ditembak merupakan korban sampingan KKB yang marah karena salah seorang pekerja mengambil foto upacara perayaan HUT Tentara Pembebasan Nasional Organisasi Papua Merdeka (TPN/OPM). Kompas.com menulis, pada saat kejadian, KKB berada tidak jauh dari lokasi.

Sedangkan pada pemberitaan BBC.com menyebutkan, penembakan 31 pekerja jalan dan jembatan tersebut dilakukan oleh KKB yang masih terkait dengan OPM. BBC.com tampak hati-hati menulis ket- erkaitan KKB dengan OPM. BBC.com melihat peristiwa penembakan di tengah pembangunan infrastruktur di Papua menjadi rumit dan pelik. Lewat dua narasumber dari Komite Nasional Papua Barat (KNPB), LIPI dan KontraS, BBC.com mengetengahkan bahwa adanya pembangunan tidak serta merta dapat menyelesaikan persoalan kekerasan dan perselisihan di Papua, karena persoalannya bukan sebatas ekonomi dan pembangunan (bbc.com, 5 Desember 2018).

Pemberitaan yang berbeda ditemukan pada berita Tabloidjubi.com. Menurut media ini, penembakan pekerja jalan Trans Papua dilakukan kelompok bersenjata pimpinan Egianus Kogoya (Tabloidjubi.com, 5 Desember 2018). Tabloidjubi.com menulis penyebab penembakan para pekerja berawal dari aksi protes warga kepada anggota TNI yang mengambil foto warga saat beribadah. Warga meminta foto tersebut dihapus, namun ditolak hingga menimbulkan aksi tembak menembak di dekat pos tentara.

Perbedaan pemberitaan pada tiga media tersebut menunjukkan masing-masing media memiliki sudut 
pembingkaian yang berbeda. Menurut Entman, pembingkaian media dipengaruhi oleh dua hal, pertama, pemilihan aspek tertentu dari realitas yang ada. Kedua, dari realitas yang dipilih, media melakukan penonjolan untuk mempromosikan definisi masalah, interpretasi, evaluasi dan rekomendasi solusi tertentu (Entman 1993, h. 52). Dari dua hal itu kemudian, realitas yang dikonstruksi media hanya menunjukkan salah satu sisi sesuai keinginan masing-masing media sebagai pembuat teks.

Ketika media hanya membingkai dari salah satu sisi realitas, maka ada sisi-sisi lain yang diabaikan yang berpotensi merugikan pihak-pihak tertentu antara lain warga terdampak langsung konflik seperti warga setempat dan juga pendatang. Pembingkaian berita konflik idealnya diikuti dengan penggunaan perspektif jurnalisme damai. Jurnalisme damai (peace journalism) memfasilitasi media dan jurnalis untuk menginisiasi perdamaian, meredakan perbedaan, mencegah konflik berlanjut dan memberikan suara kepada semua pihak serta menciptakan empati dan pengertian (Fong, 2009, h. 19). Jurnalisme damai juga mampu menurunkan ketegangan dengan membuat pemberitaan yang jujur, tekad dan komitmen para media dan jurnalis untuk menyediakan pemberitaan yang mampu menyelesaikan masalah secara damai (Lynch dan McGoldrick 2005, h. 17). Prinsipnya, jurnalisme damai melaporkan suatu kejadian dengan bingkai lebih luas, lebih berimbang, dan lebih akurat yang mengarah pada penyampaian informasi yang berdampak pada perdamaian.

Penelitian terkait penggunaan perspektif jurnalisme damai dalam liputan konflik pernah dilakukan oleh Seow Ting Lee (2010). Lee (2010) dalam artikelnya berjudul "Peace Journalism: Principles and Structural Limitations in the News Coverage of Three Conflicts" menganalisis 1.973 berita konflik Asia dari surat kabar berbahasa Inggris dan sehari-hari (vernaculer) di empat negara: India, Pakistan, Sri Lanka dan Indonesia. Hasilnya menunjukkan bahwa liputan konflik tersebut didominasi oleh jurnalisme perang dibandingkan jurnalisme damai khususnya pada surat kabar berbahasa Inggris. Secara khusus temuan di Indonesia, Jakarta Post dan Kompas memiliki perbedaan yang signifikan dalam memberitakan konflik Maluku dan Aceh. Lee (2010, h. 372) menemukan sebanyak
53,8\% dari 182 berita di Jakarta Post dibingkai dalam perspektif jurnalisme perang, 46,2\% dibingkai dalam perspektif jurnalisme damai. Sedangkan Kompas, $34,5 \%$ dari 116 berita dibingkai dalam perspektif jurnalisme perang dan $65,6 \%$ dibingkai dalam perspektif jurnalisme damai.

Penelitian Lee (2010) tersebut masih sama dengan temuan Lee \& Maslog (2005) di mana surat kabar berbahasa Inggris Jakarta Post dominan menggunakan bingkai jurnalisme perang yakni sebesar 48\% dari 189 berita dalam meliput konflik Gerakan Aceh Merdeka dan Konflik Maluku. Yang menarik dari temuan ini adalah ada perbedaan bingkai jurnalisme perang Jakarta Post dalam liputan konflik Aceh dengan Maluku. Pada konflik Maluku, pembingkaian Jakarta Post dominan menggunakan perspektif jurnalisme perang sebanyak 63,3\% dari 79 berita, dibandingkan pada konflik Aceh sebesar 37,3\% dari 110 berita.

Sedangkan penelitian yang dilakukan oleh Juditha (2016) pada Tempo.co terkait berita konflik antar umat beragama di Tolikara, Papua pada 2015 menunjukkan $86,49 \%$ berita Tempo.co telah mengarah pada orientasi perdamaian. Kendati demikian, Tempo.co gagal memberikan ruang bagi pihak-pihak yang terkait konflik langsung, dan masih dominan mengandalkan pendapat elit, aparat keamanan, tokoh agama (Juditha 2016, h. 102).

Penelitian-penelitian tersebut menggunakan surat kabar dan media online berskala nasional untuk melihat bagaimana konflik diberitakan. Sebagaimana ditunjukkan Lee \& Maslog (2005) dan Lee (2010), penggunaan perspekif jurnalisme perang dominan dalam bingkai Jakarta Post dibandingkan Kompas (Lee, 2010) dan Tempo.co (Juditha, 2016). Namun demikian, penggunaan perspektif jurnalisme damai di Kompas dan Tempo.co juga belum menunjukkan hasil yang memuaskan. Dalam hal ini kedekatan media pada lokasi dan sumber berita menjadi salah satu instrumen penting dalam proses framing selain bahasa. Jakarta Post, Kompas dan Tempo.co yang berlokasi di Ibu Kota tentu membawa konsekuensi dalam proses perolehan data (news gathering) yang jauh dari lokasi, pihak terkait dan terdampak di wilayah konflik. Sehingga pemberitaan ketiganya belum mampu menghadirkan 
kebenaran dari semua sisi.

Penelitian ini menjadi penting berkontribusi dalam melihat apakah media lokal mampu menyuguhkan berita yang berperspektif damai. Tabloidjubi.com sebagai media lokal idealnya memberitakan kasus konflik bersenjata di Nduga secara lebih jernih, akurat, seimbang dan mengarah pada perdamaian. Kasus konflik bersenjata di Nduga, Papua masih banyak menyimpan permasalahan yang panjang, seperti munculnya dendam dalam masyarakat yang dapat melibatkan korban dan kerugian material. Melalui jurnalisme damai memberitakan konflik secara apa adanya dan memberikan porsi yang seimbang kepada semua pihak merupakan hal yang tepat dalam mewujudkan perdamaian. Dan jurnalis sebagai pembawa berita harus mampu menerapkan Kode Etik Jurnalistik Pasal 1-3 bersikap independen, menghasilkan berita yang akurat, berimbang dan tidak beritikad buruk, profesional, dan selalu menguji informasi, tidak mencampurkan fakta dan opini yang menghakimi, serta menerapkan asas praduga tak bersalah.

Artikel ini secara khusus membahas apakah Tabloidjubi.com dalam bingkai pemberitaan konflik bersenjata di Nduga Papua telah berperspektif jurnalisme damai? Tujuannya untuk memperlihatkan cara kerja Tabloidjubi.com dalam menyeleksi, dan menonjolkan realitas dari peristiwa konflik bersenjata di Nduga apakah telah mengarah pada perdamaian atau justru lebih fokus pada konfliknya, serta apakah telah mengarah pada kebenaran, kepentingan orang banyak dan memberikan solusi untuk mencegah terjadinya konflik

\section{KAJIAN PUSTAKA}

Metodologi

Penelitian ini menggunakan pendekatan penelitian kualitatif-deskriptif (Kriyantono 2014, h. 69). Pengambilan sampel menggunakan nonprobability dengan jenis purposive/judgmental sampling (Babbie 2014, h. 200). Adapun kriteria yang digunakan peneliti yakni: ketika peristiwa berlangsung (situasi konflik), peristiwa pemicu konflik, dan setelah peristiwa berlangsung (upaya perdamaian). Dari 45 berita yang diterbitkan oleh Tabloidjubi.com pada edisi Desember 2018 hanya 15 berita yang sesuai dengan kriteria sampel.

Teknik analisis yang digunakan dalam penelitian ini menggunakan analisis framing model Robert N. Entman. Melalui model Robert N. Entman, konsep framing digunakan untuk menggambarkan proses seleksi dan penonjolan aspek tertentu dari realitas oleh media. Framing dipandang sebagai penempatan informasi-informasi dalam konteks yang khas sehingga isu tertentu mendapatkan alokasi lebih besar daripada isu yang lain (Eriyanto 2011, h. 220).

Robert N. Entman menggambarkan proses seleksi isu dan penonjolan aspek-aspek dari realitas ke dalam empat bentuk elemen konsep framing (dalam Eriyanto 2011, h. 223-227): (1) Bingkai masalah (define problems), elemen ini merupakan bingkai yang paling utama (master frame) yang menekankan bagaimana peristiwa dipahami oleh jurnalis. penyebab masalah (diagnose cause), merupakan elemen framing yang membingkai siapa yang dianggap sebagai aktor dari suatu peristiwa. (3) pertimbangan moral (make moral judgement), elemen framing yang dipakai untuk membenarkan atau memberi argumentasi pada pendefinisian masalah yang sudah dibuat. (4) Rekomendasi (treatment recommendation), elemen ini dipakai untuk menilai apa yang dikehendaki oleh jurnalis, jalan apa yang dipilih untuk menyelesaikan masalah/isu.

\section{Kajian Konseptual}

\section{Jurnalisme Damai}

Istilah jurnalisme damai diusulkan oleh Johan Galtung melalui artikelnya berjudul "The Structure of Foreign News: The Presentation of the Congo, Cuba and Cyprus Crises in Four Norwegian Newspapers" yang ditulis bersama Mari Holmboe Ruge (Galtung \& Ruge, h. 1965). Artikel tersebut merupakan kritik terhadap pemberitaan empat surat kabar Norwegia terkait krisis Kongo dan Kuba pada Juli 1960 dan krisis Siprus pada Maret-April 1964 yang hanya fokus pada konflik perangnya. Johan Galtung adalah seorang profesor perdamaian serta pendiri sekaligus direktur 
TRANSCEND: a network for peace, development and environment di mana gagasan jurnalisme damai terus ia kembangkan. Galtung (1986/1998) mengatakan orientasi jurnalisme damai pertama-tama harus menerima dan mengakui bahwa konflik itu ada sebelum mengeksplorasi dan mengidentifikasi pihak, tujuan dan masalah dari konflik.

Namun demikian, Galtung dan Ruge menolak konflik sebagai nilai berita dalam pemberitaan. Menurut keduanya, ketergantungan jurnalis terhadap konflik telah membawa dampak serius pada pemberitaan yang sensasional, dominasi satu pihak, penekanan berlebihan pada kerugian material dan korban jiwa, bahasa kemenangan militer, serta narasi yang dangkal (Lee, 2010, h. 362). Karena itu, jurnalis dan media diminta fokus pada transformasi konflik dengan cara "transform the conflict creatively so that the opportunities take the upper hand-without violence" (Galtung, 1998, h. 23).

Galtung (1998 dalam Lynch \& McGoldrick, 2007, h. 256) mendefinisikan jurnalisme damai sebagai pendekatan yang fokus pada "hasil non-kekerasan, empati dengan semua pihak dan kreativitas yang membawa perdamaian". Sementara Lynch \& McGoldrick, 2007, h. 256) mendefinisikan, jurnalisme damai adalah ketika editor dan jurnalis memilih cerita tertentu untuk diinformasikan, dengan tujuan menciptakan peluang bagi masyarakat luas untuk menilai respon nonkekerasan pada konflik. Dengan adanya konsep jurnalisme damai seharusnya editor dan jurnalis ketika memilih cerita, mereka mengedepankan upaya-upaya untuk menciptakan perdamaian dan respon-respon yang tidak membangkitkan kekerasan.

Lynch \& McGoldrick (2005, h. 26) melanjutkan, jurnalisme damai sebagai alat analisis dan transformasi konflik untuk memperbaharui konsep keseimbangan, keadilan dan akurasi dalam pelaporan peristiwa. Melalui pendekatan jurnalisme damai dapat memberikan sebuah jalan baru, ketika menelusuri hubungan jurnalis dengan sumber-sumber berita dan peristiwa yang mereka sajikan, untuk melihat konflik tidak hanya memiliki konsekuensi dalam etika jurnalistik, namun pula memiliki konsekuensi yang lebih luas secara hukum dan hak asasi manusia. Maka dalam jurnalisme damai, intervensi jurnalistik sangat dibutuhkan untuk membangun nirkekerasan dan kreativitas dengan ide baru untuk memecahkan masalah yang ada dalam konflik, sehingga membuka kesadaran dan pengetahuan bagi khalayak (Lynch dan Galtung, 2010).

Selanjutnya, Samuel Peleg menjelaskan jurnalisme damai sebagai upaya berani mendefinisikan dan merekonstruksi peran jurnalis yang meliput konflik (Peleg 2006, h. 1). Peleg memperkenalkan bahwa dalam praktik jurnalisme damai, jurnalis adalah pihak ketiga yang memiliki peran menjadi mediator komunikasi yang merangsang motivasi yang positif dalam mengurangi ketegangan konflik di antara kedua belah pihak (Peleg 2006, h. 1-2).

Johan Galtung (dalam Lynch \& McGoldrick, 2007, h. 251) menerapkan beberapa prinsip jurnalisme damai, sebagai berikut: Pertama, berorientasi pada perdamaian atau konflik. Jurnalisme damai mengeksplorasi terbentuknya konflik, sebab ada banyak pihak yang terlibat, ada banyak tujuan, dan ada banyak isu yang berkembang. Dalam hal ini, tujuan utama jurnalisme damai adalah memetakan konflik, mengidentifikasi pihak-pihak yang terlibat, dan menganalisis tujuan-tujuan pihak-pihak terkait.

Selain itu jurnalisme damai harus menggunakan pendekatan "win-win solution" untuk menyelesaikan konflik. Dalam hal ini jurnalisme damai melihat pertikaian sebagai permasalahan yang seharusnya tidak terjadi. Jurnalisme damai memberikan porsi yang sama kepada kedua bela pihak untuk memunculkan pendapat masing-masing, namun dalam hal ini para jurnalis berusaha menghindari pesan yang menyalahkan salah satu pihak sebagai penyebab konflik. Sehingga, jurnalis tidak memvonis siapa yang kalah dan menang, namun menyelesaikan konflik secara damai, dengan menempatkan kepentingan masyarakat luas di atas kepentingan kelompok atau golongan tertentu dalam konflik.

Selanjutnya melalui praktik jurnalisme damai, konflik dapat terlihat transparan. Caranya, jurnalis memaparkan semua masalah yang sebenarnya terjadi dan dampak apa yang telah ditimbulkan dari konflik tersebut. Selain itu, jurnalis juga harus berempati dan mengedepankan suara orang-orang lemah daripada 
kelompok yang bertikai dalam konflik. Kemudian, jurnalisme damai melihat bahwa konflik atau perang sebagai masalah, dalam hal ini jurnalis berfokus pada kreativitas konflik, dengan maksud jurnalis memunculkan ide-ide baru untuk memecahkan masalah, sehingga mampu mencegah terjadinya kekerasan

Kedua, berorientasi pada kebenaran. Jurnalisme damai harus selalu berusaha untuk mengekspos kebohongan dan semua hal yang ditutup-tutupi dari segala sisi. Dalam hal ini, jurnalis menggali semua kebohongan dengan mengungkapkan akar masalah yang terkait mulai dari sejarah, psikologis, sosial, dan budaya. Dengan demikian, jurnalis mampu mengungkapkan kebenaran lebih luas dan lengkap.

Ketiga, berorientasi pada orang banyak. Dalam hal ini jurnalisme damai memfokuskan diri untuk melihat penderitaan semua orang yang terkait dalam konflik dengan menyuarakan suara orang-orang yang lemah, orang tua, perempuan, dan anak-anak untuk mendapatkan tempat lebih banyak dalam pemberitaan, dibandingkan dengan porsi pemberitaan para elit yang bertikai. Selain itu, jurnalisme damai juga memfokuskan pemberitaannya pada berita nirkekerasan, yaitu pada efek kekerasan yang tidak tampak, seperti kerusakan sosial dan budaya moral, kerusakan material sehingga menyebabkan kerugiaan, kerusakan yang menyebabkan korban trauma, terluka, meninggal, serta mengungkap semua pelaku kejahatan. Dalam hal ini, tidak termasuk dengan produk kekerasan semata, seperti potongan mayat, pemerkosaan, dan rumah ibadah yang hangus. Hal ini bertujuan untuk menarik empati khalayak bahwa konflik yang disertai kekerasan hanya mendatangkan kerugian. Tidak lupa memberikan porsi yang memadai bagi pihak-pihak yang menciptakan perdamaian (peace maker).

Keempat, berorientasi pada solusi, Jurnalisme damai menekankan inisiatif perdamaian dan mencegah lebih banyak perang. Di mana seorang jurnalis harus menjadi pihak yang nirkekerasan dan kreatif memulihkan keadaan. Jurnalis bisa menjalankan hal ini melalui, (1) resolusi berupa kemampuan menangani dan memecahkan permasalahan dalam konflik yang kemudian membangun suatu hubungan baru yang dapat bertahan lama di antara kedua belah pihak yang bertikai., (2) rekonstruksi, membangun upaya pemulihan keadaan seperti sebelum konflik terjadi, melalui penyampaian informasi yang berimbang, adil dan akurat, dan (3) rekonsiliasi, melakukan upaya pemulihan hubungan kedua belah pihak seperti semula dengan menyelesaikan perbedaan antara kedua belah pihak yang berada dalam konflik.

Dengan demikian, jurnalisme damai harus mampu menyatakan suatu peristiwa konflik melalui kacamata yang mereka lihat langsung di lapangan dengan menceritakan peristiwa konflik sebagaimana yang terjadi, tanpa harus menuntup-nutupi sesuatu yang menguntungkan satu pihak dan merugikan pihak lain. Selain itu, jurnalisme damai harus mampu melaporkan pesan-pesan yang bersifat propaganda, tidak menciptakan informasi yang menyebarkan ketidakbenaran atau kebencian di antara kedua belah pihak yang saling menyebarkan tuduhan satu sama lain. Dengan konsep jurnalisme damai, jurnalis dapat melihat fakta mana yang harus dipilih dan bagaimana meliput dan membingkainya secara adil dan akurat sehingga dapat menggambarkan peristiwa dengan jernih (Peleg 2006, h.11-14).

\section{HASIL DAN DISKUSI}

Hasil penelitian dibagi menjadi empat temuan: (1) berita yang berorientasi perdamaian atau konflik, (2) berita yang berorietasi pada kebenaran, (3) berita yang berorientasi pada orang banyak, (4) berita yang berorientasi pada solusi. Pada bagian penjelasan, tidak semua berita digunakan untuk menjelaskan temuan. Hanya berita yang menonjolkan masing-masing kategori temuan yang akan digunakan.

\section{Berorientasi perdamaian/konflik}

Dari hasil analisis menunjukkan pemberitaan Tabloidjubi.com masih mengarah pada konflik daripada perdamaian. Salah satunya ditemukan pada berita berjudul "24 pekerja jalan trans Papua di Nduga tewas dibunuh" (4 Desember 2018). Pada berita ini berdasarkan kutipan pernyataan dari Wakil Ketua DPRD Nduga Alimi Gwijange, Tabloidjubi.com menonjolkan pihak kelompok bersenjata pimpinan Egianus Kogoya 
yakni Tentara Pembebasan Nasional Papua Barat (TPNPB) sebagai pelaku pembunuhan 24 pekerja pembangunan jalan Trans Papua di Nduga. Dalam berita ini, media melegitimasi kelompok bersenjata sebagai pelaku dan penyebab masalah.

Sementara pada berita berjudul "Benny Wenda: Berita pembunuhan di Nduga adalah propaganda Indonesia" (5 Desember 2018) menunjukkan konflik di Nduga merupakan wujud propaganda bangsa Indonesia, agar masyarakat luas percaya bahwa orang Papua brutal. Dengan alasan tersebut masyarakat Indonesia melegitimasikan pengiriman pasukan lebih besar ke Papua.

“Kami juga minta TNI Polri tidak menakutnakuti rakyat kecil di sana, jangan berpikir masyarakat itu OPM sehingga main tembak saja, jangan berfikir semua orang dianggap OPM," tegas Gwijangge Ketua DPRD.

Pernyataan di atas menunjukkan kehadiran TNI/Polri semakin memanaskan situasi konflik yang dapat berdampak buruk pada masyarakat Papua khususnya di Nduga.

Kemudian, dalam berita berjudul "TPNPB: Itu serangan bersenjata, bukan eksekusi” (5 Desember 2018) memaparkan bahwa Tentara Pembebasan Nasional Papua Barat (TPNPB) membuka suara terkait dugaan pembunuhan yang dituduhkan kepada mereka. Dan pihak TPNPB mengaku sebagai pihak yang bertanggung jawab atas penembakan beberapa orang yang disebut sebagai karyawan PT Istaka Karya yang tengah membangun jalan Trans Papua. Namun demikian, TPNPB mengklaim peristiwa tersebut bukan pembunuhan melainkan kontak senjata.

"Kami yang bertanggung jawab. Ada kontak senjata. Itu serangan bersenjata, bukan eksekusi seperti yang disampaikan aparat keamanan Indonesia," ungkap juru bicara TPNPB, Sebby Sambom kepada Jubi melalui sambungan telepon, Rabu (5/12/2018), membantah keterangan aparat keamanan Indonesia yang menyebutkan para pekerja dibunuh dengan cara eksekusi.
Penekanan pada kata "kontak senjata" atau "serangan bersenjata" dan "bukan eksekusi" menunjukkan bahwa yang dilakukan merupakan bagian dari perlawanan terhadap anggota militer dan bukan terhadap pekerja sipil. Artinya, ada upaya mewajarkan tindakan "serangan bersenjata" yang dilakukan oleh TPNPB. Di sisi lain, penyusunan fakta dan data dalam berita ini semakin meneguhkan tindakan "serangan bersenjata" TPNPB tersebut.

Pada tahun 2016, Kementerian Pekerjaan Umum dan Perumahan Rakyat (PUPR) menjadikan Zeni TNI AD sebagai mitra kerja membuka trans Papua.

Zeni Angkatan Darat mengerahkan sejumlah 394 orang personel...

“...Selama ini TPNPB juga tahu yang berkerja pada proyek Jalan Trans dan JembatanJembatan yang ada sepanjang Jalan Habema, Juguru, Kenyam hingga Batas Batu adalah Anggota TNI," jelas Sebby.

Sekalipun orang-orang tersebut berpakaian sipil atau preman, mereka tetap saja anggota militer.

Kemudian, masih pada berita yang sama, Tabloidjubi.com mengutip kembali perkataan Sebby Sambom yang menyebutkan TPNPB bukanlah kelompok kriminal sebagaimana yang sering disebutkan oleh aparat keamanan Indonesia. TPNPB menolak disebut sebagai kelompok kriminal. Bagi mereka, "TPNPB adalah tentara pembebasan nasional rakyat Papua Barat yang bertujuan membebaskan Papua Barat dari Indonesia." Melalui pemberitaan ini, Tabloidjubi.com memberikan ruang kepada pihak Tentara Pembebasan Nasional Papua Barat (TPNPB) untuk menegaskan identitas mereka sebagai pejuang pembebasan (freedom fighter). Dengan demikian, setiap tindakan mereka dimaknai sebagai sesuatu yang positif untuk perjuangan Papua Barat.

Pada pihak sebaliknya yakni pihak pemerintah, Tabloidjubi.com dalam berita berjudul: "Lukas Enembe: "Amankan rakyat dan tangkap kelompok bersenjata di Nduga" (28 Desember 2018) memberi ruang kepada Gubernur Papua Lukas Enembe dan Kapolda Papua, Irjen Pol Martuani Sormin. Martu- 
ani Sormin misalnya memastikan bahwa korban penembakan TPNPB tersebut adalah warga sipil. Sementara, Lukas Enembe meyakini bahwa pelakunya adalah kelompok bersenjata pimpinan Egianus Kogoya. "Kami harap, para pelaku penembakan harus dikejar sampai dapat," kata Enembe dengan tegas.

Dari pemberitaan ini memperlihatkan Tabloidjubi.com telah berusaha mengungkap terbentuknya konflik, dengan melihat pihak yang terkait, tujuan dari masing-masing pihak, dan isu-isu yang muncul akibat konflik. Namun demikian, Tabloidjubi.com belum membuat konflik menjadi transparan, dan belum mengeksplorasi lebih lanjut semua pihak yang terkait konflik. Pada masing-masing pemberitaannya, media ini masih dominan mengutip pernyataan salah satu pihak baik dari sisi TPNPB, TNI/Polri, maupun dari pemerintah pusat dan daerah. Sementara pihak lain yang terkait lainnya tidak tampak dalam pemberitaan. Padahal, dalam perspektif jurnalisme damai memberikan suara kepada semua pihak serta berempati kepada pihak terkait sangat penting. Akibatnya, konflik tampaknya hanya bergerak dalam lingkaran pihakpihak itu saja.

Selain itu, pernyataan seperti "pembunuhan di Nduga adalah propaganda Indonesia", "orang Papua brutal”, "TPNPB adalah kelompok kriminal”, “ TNI/ Polri menakut-nakuti rakyat kecil" dan lain sebagainya semakin meningkatkan permusuhan antara pihak yang bertikai. Padahal, McGoldrick \& Lynch (2001 dalam Soerjoatmodjo 2010, h. 185) telah mengingatkan bahwa media sejatinya berusaha meminimalkan keretakan antara pihak yang berlawanan dengan cara tidak menjelekkan pihak tertentu atau menyiapkan panggung untuk konflik.

Di samping itu, upaya untuk memanusiakan semua pihak, mencegah konflik semakin memanas, serta menciptakan inisiatif perdamaian belum tercipta. Tabloidjubi.com sebagai mediator komunikasi dalam konflik seyogyanya mengupayakan penyelesaian dan rekonsiliasi antar pihak yang bertikai, meredakan konflik dan mencegah penguatan perselisihan (Peleg, 2006, h. 14-15).

\section{Berorientasi Kebenaran}

Tabloidjubi.com mengungkapkan kebenaran dalam konflik di Nduga, dengan memberitakan akar masalah dan pernyataan keliru terkait penyebab konflik. Hal ini misalnya ditemukan pada berita berjudul "Gereja: Insiden Nduga Berawal Dari Aksi Protes Warga" (5 Desember 2018) dan "Ini Kesaksian Korban dan Mantan Pekerja Proyek di Yall Nduga” (5 Desember 2018). Tabloidjubi.com memaparkan bahwa penyebab terjadinya konflik karena Presiden Joko Widodo melimpahkan kewenangan kepada TNI untuk mengamankan proses pembangunan jalan trans Papua. Jurnalis Tabloidjubi.com menggambarkan bahwa pelimpahan tersebut ditolak oleh sayap militer Organisasi Papua Merdeka (OPM) dengan mengancam akan melakukan perang.

Pada berita berikutnya disebutkan bahwa pembunuhan 24 pekerja pembangunan jalan trans Papua disebabkan karena pelanggaran perjanjian. Tabloidjubi.com menyampaikan, pada 2017 OPM bersama perusahaan sudah pernah membuat perjanjian bahwa setiap 24 November hingga Desember, pekerjaan proyek jalan Trans Papua dihentikan. Mess atau tenda harus dikosongkan karena pada 1 Desember merupakan peringatan kemerdekaan kelompok bersenjata.

Paska-konflik terjadi, pihak dari pemerintah melalui aparat keamanan TNI/Polri melakukan proses evakuasi dan pengejaran pelaku serangan senjata, dan telah menguasai seluruh wilayah di Nduga. penguasaan wilayah tersebut dan proses pengejaran tersebut membuat masyarakat sipil yang tidak terkait dalam masalah konflik tersebut menjadi korban.

Tabloidjubi.com melihat aparat keamanan telah melanggar kebebasan masyarakat sipil. Sehingga melalui temuan ini, menunjukkan bahwa berita-berita yang diterbitkan oleh Tabloidjubi.com masih berfokus pada pertikaian antara dua pihak ini.

Selanjutnya, ditemukan berita yang meluruskan fakta keliru yang menganggap kondisi Nduga aman. Tabloidjubi.com mengutip pernyataan narasumber Ketua tim evakuasi pemerintah Kabupaten Nduga, Elieser Tabuni:

"Masyarakat masih dalam pengungsian. Itu karena masih adanya operasi yang dilakukan aparat keamanan di sejumlah distrik tersebut. 
Sehingga jika ada yang bilang situasi di Nduga baik-baik atau aman-aman saja itu harus diralat," katanya kepada Jubi di Wamena, Kamis (27/12/2018).

Ia mengatakan komentar Matius Murib, Direktur PAK HAM Papua yang mengatasnamakan aktivis Hak Asasi Manusia di Papua di sejumlah media online dan juga sosial media yang menyebutkan situasi di Nduga amanaman saja sangat tidak benar karena yang bersangkutan hanya sampai di distrik Mbua.

Berdasarkan pernyataan tersebut, Tabloidjubi.com telah menunjukkan kekeliruan yang tidak sesuai dengan fakta lapangan. Bahwa berdasarkan fakta-fakta dan konflik yang terus terjadi, kondisi Nduga belum bisa dikatakan aman. Hal ini berguna mencegah korban lanjutan yang tidak waspada karena menganggap kondisi sudah aman.

Namun demikian, karena Tabloidjubi.com masih fokus pada kedua belah pihak terkait, maka kebenaran dari semu pihak menjadi terabaikan. Sebagaimana disampaikan oleh Lynch \& McGoldrick (2005, h. 5) bahwa "selalu ada lebih dari dua pihak dalam konflik... yang keterlibatan atau kepentingannya tersembunyi, [sehingga] perlu dicatat." Artinya, Tabloidjubi.com masih perlu mengidentifikasi apa dan siapa yang tidak tampak sebelum konflik, pada saat konflik berlangsung ataupun paska konflik.

\section{Berorientasi Orang Banyak}

Dalam orientasi ini, Tabloidjubi.com memberitakan cukup banyak terkait warga yang menjadi korban konflik. Di mana adanya penderitaan yang dialami masyarakat lokal yang menjadi korban meninggal, dan terluka akibat serangan senjata yang telah dilakukan baik oleh pihak TPNPB maupun aparat TNI/ Polri.

Korban tewas misalnya diberitakan antara lain pada berita berikut: "TPNPB: itu serangan bersenjata, bukan eksekusi" (5 Desember 2018), disebutkan ada 20 orang menjadi korban dalam pembunuhan di Nduga Papua. 19 orang adalah pekerja PT Istaka Karya dan satu personel TNI. Sedangkan dari pihak aparat kea- manan TNI/Polri ditemukan pada berita berjudul "Sejak evakuasi dilakukan, empat warga dilaporkan tewas, lainnya mengungsi ke hutan" (9 desember 2018). Ada empat warga sipil tewas paska insiden penembakan karyawan PT Istaka Karya, tiga klasis mengungsi ke hutan-hutan, dan ada empat orang lukaluka akibat proses pengejaran melalui serangan penembakan dari pesawat.

Sedangkan korban yang mengungsi misalnya ditemukan dalam berita berikut: "Gereja: Ratusan keluarga di Nduga mengungsi ke hutan" (9 Desember 2018).

"Pendeta Benny Giay merinci 5 klasis tersebut adalah Klasis Yigi Barat sebanyak 6 jemaat, Klasis Yigi sebanyak 6 jemaat, Klasis Mbua sebanyak 6 jemaat dan Klasis Mbulmuyalma sebanyak 8 jemaat. Satu klasis lainnya, yakni Klasis Mugi belum diketahui pasti berapa jemaat yang mengungsi.

"Masing-masing jemaat itu rata-rata diisi oleh 30-50 kepala keluarga. Jadi jumlah yang diketahui mengungsi dari empat klasis itu ada sekitar 780 kepala keluarga. Jika 1 keluarga dua orang saja, sudah lebih dari 1500 orang yang mengungsi," jelas Pendeta Benny Giay. “...pada peristiwa penyisiran sebelumnya yang terjadi pada bulan Juni-Juli 2018, 50 keluarga di Kampung Alguru yang disebut sebagai tempat persembunyian kelompok bersenjata telah mengungsi ke hutan. Selain itu, ada sekitar 150 orang yang mengungsi ke Timika dan 116 orang keluar dari Nduga menuju Agats, Asmat.

Pada berita lain yang berjudul "Sejak evakuasi dilakukan empat warga Nduga dilaporkan tewas lainnya mengungsi ke hutan" Tabloidjubi.com menjelaskan bahwa ada empat warga sipil yang ditembak aparat saat menjalankan proses evakuasi 16 korban penembakan pada 2-3 Desember 2018. Media ini melihat aparat keamanan gagal melindungi dan menjaga keselamatan warga setempat paska penembakan. Di samping itu, akibat konflik ini, makin menambah korban karena kekurangan makanan dan masalah 
kesehatan selama mengungsi.

Selanjutnya, pada berita berjudul "Lembaga dan aktivis HAM minta aparat tidak membabi buta", Tabloidjubi.com memberi ruang bagi individu maupun kelompok yang mampu menginisiasi perdamaian. Lembaga Amnesti International misalnya, ikut menyuarakan agar respon aparat keamanan atas serangan penembakan di Nduga tidak mengarah pada pelanggaran hak azasi manusia lebih lanjut serta aparat kemanan bisa memberikan keamanan bagi semua orang, tanpa diskriminasi (7 Desember 2018). Sementara, berita berjudul "Konflik Nduga, Pemerintah diminta membuka akses dan perlindungan terhadap warga sipil” menghadirkan Eir Gwijangge ketua tim Solidaritas Peduli Rakyat Nduga menilai operasi militer yang dilakukan TNI/Polri brutal dan tidak sesuai dengan kemanuasian karena korban sipil terus bertmbah hinggal 12 orang.

"Mereka ini ditembak melalui serangan udara di enam distrik. Pemerintah Indonesia sudah melakukan kejahatan kemanusiaan terhadap warga sipil yang tidak tau apa-apa, karena serangan yang dilakukan tersebut tidak mengarah kepada kelompok TPNPB Egianus Kogoya, namun mengarah ke warga sipil yang tidak berdosa," katanya.

Berita-berita tersebut telah memberikan ruang bagi korban terdampak secara umum, meski tidak dijelaskan secara lebih detail dampak konflik secara khusus kepada perempuan, anak-anak dan orangtua yang merupakan kelompok paling rentan. Hal ini kemudian menunjukkan bahwa berita-berita terkait dampak material maupun korban meninggal saja tidak cukup, karena diperlukan pemberitaan yang memperlihatkan efek kekerasan non-material seperti trauma emosional dan kerusakan struktur sosial (Fong, 2009, h. 19).

Ruang bagi suara individu maupun kelompokkelompok terkait konflik juga belum tampak memadai dalam pemberitaan Tabloidjubi.com selama periode berita ini. Termasuk bagi orang-orang yang mampu menginisiasi perdamaian (peace maker) khususnya yang mampu memulihan hubungan dan menyelesaikan perbedaan antara pihak-pihak yang terkait konflik belum cukup digali.

\section{Berorientasi Solusi}

Dalam pemberitaan konflik bersenjata di Nduga Papua, Tabloidjubi.com belum cukup menyoroti inisiatif perdamaian dan mencegah konflik berlanjut lewat resolusi, rekonstruksi, dan rekonsilisasi. Berdasarkan hasil analisis, Tabloidjubi.com belum menekankan pada pemecahan masalah yang mengarah penciptaan ide perdamaian. Berita-berita yang dimunculkan masih melihat penyelesaian konflik secara sepihak yakni dari sisi pemerintah. Hal ini misalnya ditemukan dalam berita berikut: "Konflik Nduga, Pemerintah diminta membuka akses dan perlindungan terhadap warga sipil” (11 Desember 2018), “Gubernur dan DPR Papua sepakat tarik aparat keamanan dari Nduga" (20 Desember 2018), dan “Tim evakuasi Kabupaten Nduga: Masyarakat masih dalam pengungsian" (27 Desember 2018). Ketiga berita tersebut memberitakan permintaan kepada Presiden Joko Widodo atau pemerintah pusat untuk menarik segala operasi militer yang ada di wilayah distrik Nduga, Papua. Agar masyarakat lokal yang mengungsi bisa kembali ke kampung mereka masing-masing.

Tabloidjubi.com melihat bahwa operasi militer TNI/Polri yang telah diturunkan pemerintah pusat hanya membuat kekacauan di tengah-tengah masyarakat Papua. Masyarakat Papua disebutkan tidak setuju atas keberadaan TNI/Polri, yang rekam jejaknya telah diketahui melakukan kejahatan dan pelanggaran HAM kepada masyarakat Papua. Dengan demikian, solusi yang ditawarkan masih belum mengurangi ketegangan yang terjadi terhadap warga sipil yang terkena dampak konflik sehingga belum dapat mengembalikkan kondisi masyarakat di Nduga.

Tabloidjubi.com juga belum menekankan inisiatif perdamaian yang seharusnya dilakukan ketika meliput konflik. Media ini masih melihat konflik sekadar nilai berita dalam pemberitaan. Padahal, jurnalis berperan sebagai orang ketiga yang mampu memediasi komunikasi antar kedua belah pihak. Dengan demikian, Tabloidjubi.com belum menjadi mediator dalam pemberitaan konflik bersenjata di Nduga, Papua. 


\section{KESIMPULAN}

Penggunaan perspektif jurnalisme damai dalam bingkai pemberitaan Tabloidjubi.com terkait konflik bersenjata di Nduga Papua masih belum cukup memadai. Pertama, pemberitaan Tabloidjubi.com belum mengarah pada penyelesaian masalah. Upaya memunculkan ide-ide baru dalam menyelesaikan konflik dan mencegah berlanjutnya perang belum tampak. Tabloidjubi.com mendefinisikan konflik bersenjata di Nduga Papua sebagai masalah pelimpahan kewenangan dan pelanggaran perjanjian yang kemudian meluas ke arah konflik yang disebabkan pelanggaran hukum dan HAM. Dalam hal ini, terlihat bahwa Tabloidjubi.com mencoba mengeksplorasi terbentuknya konflik dari banyak isu yang melihat bahwa konflik di Nduga disebabkan oleh ada pihak-pihak yang memiliki tujuantujuan tertentu. Sehingga, sebagian besar dalam pemberitaannya masih dominan hanya fokus pada kedua belah pihak yang bertikai.

Kedua, dalam pemberitaannya, Tabloidjubi.com memetakan permasalahan konflik di Nduga dengan cara mengidentifikasi TPNPB dan aparat keamanan TNI/Polri sebagai pihak-pihak yang terlibat, yang mana pihak-pihak ini telah memiliki tujuan tertentu dalam menguasai wilayah Nduga, Papua. Kendati demikian, Tabloidjubi.com telah menunjukkan faktafakta lapangan, kondisi dan situasi Nduga pada masa konflik yang masih belum aman untuk didiami. Hal ini menjadi salah satu keunggulan bagi Tabloidjubi sebagai media lokal yang mampu menjangkau lokasi kejadian dan pihak-pihak terdampak konflik.

Ketiga, Tabloidjubi.com cukup memberi ruang bagi korban terdampak konflik seperti korban luka dan meninggal akibat serangan tembakan yang dilakukan TPNPB dan aparat keamanan TNI/Polri. Meski cukup disayangkan, Tabloidjubi.com lebih fokus pada efek kekerasan fisik dan material dibandingkan efek kekerasan yang tidak terlihat seperti trauma emosional dan kerusakan struktur sosial.

Keempat, Tabloidjubi.com masih melihat pencabutan operasi militer yang dilakukan aparat keamanan TNI/Polri sebagai solusi menghentikan konflik. Sedangkan upaya yang mengarah pada penciptaan resolusi konflik, rekonstruksi, dan rekonsialiasi dengan memberikan suara kepada semua pihak, menghentikan pembalasan, meredakan perbedaan antara kedua belah pihak yang bertikai belum diciptakan

\section{REFERENSI}

Babbie, E. 2014. The Basics Of Social Research. Canada: Wadsworth Cengage Learning.

BBC Indonesia. 2018. "Kerumitan Masalah Papua Di Balik Penembakan Di Nduga." BBC, Desember 5. https://www.bbc.com/indonesia/indonesia46442019

Eriyanto. 2011. Analisis Framing : Konstruksi, Ideologi, dan Politik Media. Yogyakarta: LKiS Printing Cemerlang.

Entman, R. (1993). Framing: Toward clarification of a fractured paradigm. Journal of Communication, 43(4), 51-58.

Fong, N. Y. L. (2009). Framing analysis of a conflict: War/peace journalism. The Journal of the South East Asia Research Centre for Communications and Humanities, 1(1), 17-32.

Galtung, J.; Ruge, M. H. (1965). The Structure of Foreign News: The Presentation of the Congo, $\mathrm{Cu}$ ba and Cyprus Crises in Four Norwegian Newspapers. Journal of Peace Research, 2(1), 64-90. doi:10.1177/002234336500200104

Galtung, J. (1986). On the role of the media in worldwide security and peace. In T. Varis (Ed.), Peace and communication (pp. 249-66). San Jose, Costa Rica: Universidad para La Paz.

Galtung, J. (1998, September 3-6). Peace journalism: What, why, who, how, when, where. Paper presented in the workshop, "What are journalists for?" TRANSCEND, Taplow Court, UK.

Juditha, C. (2016). Jurnalisme Dalami Dalam Berita Konflik Agama Tolikara di Tempo.co. Jurnal Penelitian Komunikasi dan Opini Publik Vol. 20 No. 2, Desember 2016: 93-110

Kriyantono, R. 2014. Teknik Praktis Riset Komunikasi, Jakarta: Kencana Prenadamedia Group.

Kompas.com. 2018. "Sebanyak 31 Pekerja Jembatan Di Nduga Papua Diduga Dibunuh KKB Karena Ambil Foto Upacara." https:// regional.kompas.com/ read/2018/12/03/22090051/sebanyak-31- 
pekerja-jembatan-di-nduga-papua-diduga-

dibunuh-kkb-karena-ambil

Lee, S.T. \& Maslog, C. C. (2005). War or Peace Journalism? Asian Newspaper Coverage of Conflicts. , 55(2), 311-329. doi:10.1111/j.14602466.2005.tb02674.x

Lee, S.T. (2010) Peace Journalism: Principles and Structural Limitations in the News Coverage of Three Conflicts, Mass Communication and Society, $\quad 13: 4, \quad 361-384, \quad$ DOI: $10.1080 / 15205430903348829$

Lynch, J. \& McGoldrick, A. 2005. Peace Journalism. London: Hawthorn Press.

Lynch, J. \& Galtung, J. (2010) Reporting Conflict: New Directions in Peace Journalism. University of Queensland Press, St Lucia.

Lynch, J. \& McGoldrick, A. 2007. Peace Journalism in Charles Webel and Johan Galtung (ed.). The Handbook of Peace and Conflict Studies. Routledge: New York.

Peleg, S. (2006). Peace Journalism through the Lense of Conflict Theory: Analysis and Practice. Conflict \& communication, 5(2), 1-17.

Soerjoatmodjo, G.W.L .(2010). Peace Journalism in Indonesia in Angela Romano (ed.) International Journalism and Democracy. Routledge: New York.

Suryani, C (2020), "DISINFORMASI PEMBAKARAN BENDERA KALIMAT TAUHID," Interaksi: Jurnal Ilmu Komunikasi, vol. 9, no. 2, pp. 76-86. https://doi.org/10.14710/ interaksi.9.2.76-86

Wardani, A. D., \& Indrayani, H (2018), "Netralitas Konten Berita Online (Analisis Framing: Berita Reuni Alumni 212 di detik.com)," Interaksi: Jurnal Ilmu Komunikasi, vol. 7, no. 1, pp. 1-7. https://doi.org/10.14710/interaksi.7.1.1-7

\section{LAMPIRAN}

24 pekerja jalan trans Papua di Nduga tewas dibunuh https://tabloidjubi.com/artikel21602-24-pekerja-jalan-trans-papua-tewasdibunuh.html
Gereja: Insiden Nduga berawal dari aksi protes war ga https://tabloidjubi.com/artikel-21679gereja--insiden-nduga-berawal-dari-aksi- protes warga.html

Ini kesaksian korban dan mantan pekerja proyek di Yall Nduga https://tabloidjubi.com/artikel21690-ini-kesaksian-korban-dan-mantan- peker ja-proyek-di-yall-nduga.html

Pemprov Papua minta aparat keamanan tangkap pelaku pembunuhan di Nduga https:// www.tabloidjubi.com/artikel-21605-pemprov -papua-minta-aparat-keamanan-tangkappelaku-pembunuhan-di-nduga.html

TPNPB: Itu serangan bersenjata, bukan eksekusi https://tabloidjubi.com/artikel-21672-tpnpb-itu-serangan-bersenjata-bukan ekseku si.html

Komnas HAM sebut pelanggaran HAM, TPNPB: Ini kontak senjata, bukan eksekusi https://tab loidjubi.com/artikel-21706-komnas-ham- sebutpelanggaran-ham-tpnpb-ini-kontak- sen jata-bukan-eksekusi.html

Sejak evakuasi dilakukan empat warga Nduga dilaporkan tewas, lainnya mengungsi ke hu tan https://tabloidjubi.com/artikel-21744sejak-evakuasi-dilakukan-empat-warga- nduga dilaporkan-tewas-lainnya- mengungsi-ke-hutan $-. h t m l$

Gereja: Ratusan keluarga di Nduga mengungsi ke hutan https://tabloidjubi.com/artikel-21770gereja--ratusan--keluarga-di-nduga-mengungsike-hutan.html

Tim evakuasi kabupaten Nduga: Masyarakat masih dalam pengungsian https://tabloidjubi.com/ masyarakat-masih-dalam-pengungsian.html

Pangdam Cenderawasih bantah ada majelis Gereja jadi korban TNI/Polri di Nduga https://tab loidjubi.com/artikel-21968-pangdamcenderawasih-bantah-ada-majelis-gereja-jadi -korban-tnipolri-di-nduga.html

Tiga warga sipil tewas di Nduga bukan anggota TPNPB https://tabloidjubi.com/artikel- 
22148-tiga-warga-sipil-yang-tewas-di-ndugabukan-anggota-tpnpb.html

Lembaga dan aktivis HAM minta aparat tidak mem babi buta https://tabloidjubi.com/artikel21714-lembaga-dan-aktivis-ham-minta- apa rat-tidak-membabi-buta.html

Konflik Nduga, Pemerintah diminta membuka akses dan perlindungan terhadap warga sipil https://tabloidjubi.com/artikel-21828-konfliknduga-pemerintah-diminta-membuka-aksesdan-perlindungan-terhadap-warga-sipil.html

Gubernur dan DPR Papua sepakat tarik aparat kea manan dari Nduga https://tabloidjubi.com/ artikel-22111-gubernur-dan-dpr-papua- sepa kat-tarik-aparat-keamanan-dari- nduga.html

Lukas Enembe : Amankan rakyat dan tangkap kel ompok bersenjata di Nduga https://tab loidjubi.com/artikel-22223-lukas-enembeamankan-rakyat-dan-tangkap-kelompok- ber senjata-di-nduga.html 